\title{
CTSK Gene
}

National Cancer Institute

\section{Source}

National Cancer Institute. CTSK Gene. NCI Thesaurus. Code C90320.

This gene is involved in osteoclastic bone resorption. 